\title{
REPRESENTASI POLITIK DALAM FENOMENA KONFLIK GOA PINDUL DI KABUPATEN GUNUNG KIDUL
}

\author{
Zulfa Harirah MS \\ Dosen Ilmu Pemerintahan, Fakultas Ilmu Sosial dan Ilmu Politik \\ Universitas Riau \\ zulfaharirahms@lecturer.unri.ac.id \\ La Ode Muhamad Muliawan \\ Dosen Ilmu Politik, Fakultas Ilmu Sosial dan Ilmu Politik Universitas Bangka \\ Belitung \\ odeubb@gmail.com \\ Mochammad Fatkhurrohman \\ Alumnus Pascasarjana UGM \\ mochammadfatur27@gmail.com
}

\begin{abstract}
ABSTRAK
Wisata Goa pindul menawarkan berbagai keindahan alam di sepanjang aliran sungai bawah tanah yang didalamnya terdapat stalaktit dan stalamit yang menjadi panorama menakjubkan bagi para pengunjungnya. Sering waktu, objek wisata Goa Pindul berubah menjadi kawasan wisata yang menjanjikan keuntungan. Namun, tidak semua pihak memiliki peluang yang sama untuk memperoleh pendapatan, sehingga ketidakadilan dalam "bagi-bagi kue" ini lah yang menjadi salah satu penyebab konflik berkepanjangan. Goa Pindul menyingkap banyak perdebatan terkait siapa pihak yang paling berhak mengelola dan mengapa berhak mengelola. Penelitian ini merupakan penelitian kualitatif dengan pendekatan studi kasus. Melalui teori representasi dari Hannah Pitkins, tulisan ini akan mengkaji mengenai pemetaan representasi politik berdasarkan 4 hal yaitu identifikasi agen, konstituen, kepentingan yang diwakili dan juga responsivitas. Hasilnya diperoleh bahwa fenomena yang terjadi di Goa Pindul yaitu keterlibatan Atik Damayanti justru memperlihatkan hal yang berbeda dari konsep yang ditawarkan oleh Hannah Pitkin. Agen tidak selamanya ditentukan atau ditujukan untuk membela kepentingan konstituen tetapi tindakan agen justru ditentukan atau ditujukan untuk memperjuangkan kepentingan elit itu sendiri dan keluarganya. Ini menunjukkan bahwa terdapat konstituen semu dalam sebuah praktek representasi. Selain itu, terdapat elit yang memainkan peran lebih dari satu jenis representasi (multi tasking). Hal ini berbeda dengan konsep representasi monopolitik yang diajukan oleh Hannah Pitkins.
\end{abstract}

\section{Kata Kunci: Representasi, Politik, Konflik, Konstituen}

\section{Pendahuluan}

Konflik yang terjadi di Obyek Wisata Goa Pindul Kabupaten Gunung Kidul menunjukkan sebuah pertarungan kuasa atas sumberdaya. Bagaimana tidak, wisata Goa Pindul berhasil meraup pendapatan kotor sebesar Rp 4,6 miliar 
pertahun. Perebutan sumberdaya tersebut menjadi sesuatu yang tidak dapat terelakkan karena berkaitan dengan pundi-pundi rupiah yang menjanjikan. Tidak semua pihak memiliki peluang yang sama untuk memperoleh pendapatan, sehingga ketidakadilan dalam "bagi-bagi kue" ini lah yang menjadi salah satu penyebab konflik berkepanjangan.

Obyek wisata Goa Pindul terletak di Desa Bejiharjo Kec. Karangmojo, Kab. Gunung Kidul, Yogyakarta. Awalnya Goa Pindul hanyalah sebuah aliran sungai yang digunakan untuk mencuci. Sebelum menjadi desa wisata, desa Bejiharjo sudah menjadi desa budaya, Menurut penuturan ketua forum desa wisata DIY yaitu Bapak Krisbiantoro, Desa Bejiharjo memiliki banyak potensi pariwisata untuk dikembangkan. Sehingga tokoh masyarakatnya mulai ikut dalam program pelatihan-pelatihan dan studi banding.

Wisata Goa pindul menawarkan berbagai keindahan alam di sepanjang aliran sungai bawah tanah yang didalamnya terdapat stalaktit dan stalamit yang menjadi panorama menakjubkan bagi para pengunjungnya. Goa Pindul disulap menjadi sebuah wisata yang kian menjanjikan dengan ribuan wisatawan yang semakin bertambah setiap tahunnya. Ini tentunya menjadi sebuah angin segar bagi para pemburu keuntungan ekonomi untuk ikut terlibat dalam pengelolaannya. Sehingga tidak mengherankan jika kemudian bermunculan kelompok-kelompok sadar wisata (Pokdarwis) yang ingin mengelola Goa Pindul.

Pada bulan Oktober 2010 diadakan acara famtur oleh pejabat Kab. Gunung Kidul di desa bejiharjo. Dan acara tersebut dimanfaatkan oleh masyarakat Bejiharjo untuk mempromosikan Goa Pindu, sehingga Bupati Goa Pindul akhirnya tertarik untuk menjadikan Goa Pindul sebagai tempat wisata. Hasil dokumentasi dari acara famtur di tampilkan di acara Festival Budaya. Pada akhirnya Goa Pindul dikukuhkan menjadi obyek wisata pada bulan Agustus 2010. Goa pindul awalnya dikelola oleh Dewa Bejo (Desa Wisata Bejiharjo) yang terdiri dari Pak Subagyo, Pak Suratmin, Pak Pramuji dan Mbah Tukijo.

Setelah berjalan sekian lama, obyek wisata Goa Pindul semakin berkembang dan banyak pengunjungnya. Hal ini lah yang kemudian menyebabkan timbulnya konflik-konflik terkait masalah siapa yang berhak mengelola dan mengapa berhak mengelola. Dari satu operator yaitu Dewa Bejo kemudian mulai bermunculan Kelompok Sadar Wisata (Pokdarwis) yang lainnya. Hingga saat ini terdapat 11 pokdarwis, namun hanya 9 Pokdarwis yang 
aktif sampai saat ini. Masing-masing pokdarwis merasa berhak untuk mengelola Goa Pindul. Selain itu juga terdapat konflik masalah kepemilikan tanah yang melibatkan Atik Damayanti dan pengelola Goa Pindul.

Diluar keuntungan yang diperoleh tersebut, Goa Pindul menyingkap banyak perdebatan terkait siapa pihak yang paling berhak mengelola dan mengapa berhak mengelola. Pihak pemilik lahan diatas Goa Pindul secara sah, yakni Atik Damayanti merasa paling berhak mengelola karena memiliki sertifkat secara legal. Namun dalam pengelolaannya, Atik Damayanti justru tidak memperoleh keuntungan atas pengelolaan Goa Pindul. Disisi lain, masyarakat juga bersikukuh berhak mengelola Goa Pindul yang menurut mereka sebagai sebuah aset publik karena terdapat sumberdaya air yang tidak boleh dimiliki oleh privat. Sehingga perseteruan ini pada akhirnya melahirkan babak konflik baru yang menyebabkan bertebarannya perwakilan-perwakilan di Goa Pindul.

Tulisan ini dimaksudkan untuk menelisik lebih dalam mengenai konflik pengelolaan Goa Pindul berdasarkan perspektif teori representasi. Prosesnya akan dilakukan dengan mengidentifikasi siapa saja aktor-aktor yang menjadi wakil dari konstituennya serta bagaimana respon wakil tersebut dalam memperjuangkan kepentingan konstituennya.

\section{Tinjauan Pustaka: Teori Representasi}

Mengkaji konflik di Obyek Wisata Goa Pindul berdasarkan teori representasi sebagai sebuah konsep dan praktik mengantarkan kita untuk menelisik lebih dalam mengenai konsep teori representasi itu sendiri dan bagaimana realita sosial yang sesungguhnya terjadi. Konsep representasi merupakan sebuah konsep sederhana yang dimaknai sebagai "to make present again", artinya tindakan yang dilakukan seorang wakil untuk menghadirkan kepentingan, pandangan, dan opini dalam sebuah pembuatan kebijakan pemerintahan. Sebagai sebuah tema kajian, representasi sudah banyak menyedot perhatian para akademisi.

Berbicara mengenai representasi biasanya akan berkaitan dengan partai politik (Ezrow, 2010), sistem pemilu (Tremblay, 2008), termasuk perubahan yang terjadi pada representasi politik (Darmawan, 2017). Kajian yang tidak kalah dominan berkaitan dengan narasi representasi perempuan dalam politik di Indonesia. Pertama, menyoal tentang regulasi dan persentase keterwakilan (kuota) perempuan dalam politik elektoral (Hendarti, 2013) (Wijaksana, 2004). 
Kedua, faktor penghambat keterwakilan perempuan dalam politik, terutama berkenaan dengan faktor sosio-kultural (Rajab, 2018) (Subiantoro, 2013). Ketiga, secara historikal representasi perempuan dalam politik di indonesia mengalami pendisiplinan melalui budaya pratriarki, teologi dan hegemoni .

Selain itu, terdapat teori representasi yang dikemukakan oleh Olle Tornquist merupakan sebuah kritikan terhadap penjelasan mengenai demokrasi yang dimaknai sebagai kebebasan dan pemilu yang adil saja. Tetapi lebih dari itu, Olle ingin melihat apakah orang yang terpilih adalah orang yang memiliki massa atau tidak. Karena idealnya, yang terpilih haruslah benar-benar memperjuangkan kepentingan massanya bukan kepentingan pribadi. Representasi menjelaskan mengenai keterwakilan seseorang untuk memperjuangkan kepentingan kelompok yang diwakilinya. Dalam teori representasi terdapat agen, konstituen, political context dan responsiveness. Agen selalu berhubungan dengan seseorang yang mewakili kelompok, konstituen merupakan pihak yang diwakili, sedangkan political context dan responsiveness berkaitan dengan cara agen merepresentasikan kepentingan konstituen.

Selain Olle Tornquist terdapat Hanna F. Pitkin, salah satu yang paling dikenal dari karya Hanna Fenichel Pitkin yang berjudul The Concept of Representation. Hanna F. Pitkin membagi representasi kedalam empat bentuk, yaitu representasi substantif yaitu aktivitas dari representative untuk benar-benar memperjuangkan kepentingan yang diwakilinya (the represented), representasi simbolik yaitu keterwakilan karena kesamaan kultur, kepercayaan, dan identifikasi, dan representasi deskriptive yaitu representasi karena adanya tingkat kemiripan antara yang mewakili dengan yang diwakili misalnya kesamaan wilayah, komunitas, kelompok, gender, dll, serta representasi formal yaitu representasi yang dilihat dari statusnya.

Konsepsi representasi menurut Hanna Pitkin terdiri atas empat hal yang menjadi indikator utama dalam teori representasi, yaitu Agen (yang mewakili), konstituen (yang diwakili), kepentingan yang diwakili, dan tindakan yang dilakukan untuk memperjuangkan kepentingan. Sehingga menjadikan 2 buah kategori yaitu stand for dan act for. Yang termasuk kedalam kategori stand for adalah representasi deskriptif, representasi simbolik, sedangkan act for adalah representasi subtantif. 
Hanna Pitkin mengemukakan empat model yang dapat digunakan untuk menjelaskan representasi politik, (Pitkin, 1967) yaitu pertama, representasi formal merupakan bentuk representasi dimana agen mewakili konstituennya secara institusional. Representasi dilihat sebagai pemilikan kewenangan untuk bertindak berdasarkan otoritas dan akuntabilitas. Dengan adanya otoritas tersebut agen dapat bertindak atas nama konstituennya, sedangkan dengan akuntabilitas maka konstituennya dapat melihat sejauh mana wakil bertindak untuk memperjuangkan kepentingan mereka.

Kedua, representasi simbolik merupakan sebuah situasi representasi dimana agen menjadi sebuah simbol atas kelompok yang diwakilinya karena kesamaa identitas, budaya, agama dan kepercayaan. Dalam hal representasi politik, agen menjadi simbol yang merepresentasikan karakteristik dari kelompok yang diwakilinya. Ketiga, representasi deskriptif menggambarkan bahwa agen mendeskripsikan konstituen yang ditandai dengan karakteristik seperti warna kulit, gender, wilayah, komunitas, profesi, kelas sosial dan kepentingan. Model ini difahami sebagai kesamaan deskriptif antara wakil dengan yang diwakili, sehingga agen sebagai cerminan konstituennya. Keempat, representasi substantif berbeda dengan representasi yang dijelaskan sebelumnya, representasi subtantif lebih menekankan pentingnya peran "standing for" yang dijalankan oleh agen terhadap konstituennya. Selain itu representasi substantif lebih menekankan pada peran "acting for" agen atas konstituennya. Agen harus mampu menjadi pihak yang memainkan peran sepenuhnya untuk memperjuangkan bertindak atas konstituennya, sehingga kepentingan-kepentingan tersebut dapat teraspirasi oleh para agen. Namun demikian Pitkin menilai keterwakilan yang baik tidak hanya terbatas pada jumlah saja.

Dalam representasi politik, orang-orang yang diwakili disebut sebagai konstituen dan yang mewakili disebut sebagai wakil rakyat atau agen. Elemen yang tidak kalah penting adalah seberapa dalam agen representasi bertindak dengan preferensi dari konstituen yang diwakilinya (Rozaki \& dkk, 2014). Pitkin berasumsi bahwa representasi yang sama antara pihak yang diwakilkan dengan yang mewakilkan tidak menjamin ide-ide yang mereka bawa akan sama dengan kelompok yang mereka wakilkan (Soraya, 2012). Hal itu juga dapat dilihat pada demokrasi perwakilan yang tidak serta merta mampu menjawab persoalan di masyarakat (Ekawati, 2014). 


\section{Metode Penelitian}

Penelitian ini merupakan penelitian kualitatif yang mencakup dua maksud penetapan fokus penelitian. Pertama, penetapan fokus penelitian adalah upaya untuk membatasi studi. Kedua, penetapan fokus berfungsi sebagai kriteria inklusi-ekskluasi, sehingga memudahkan dalam memilah mana data yang sesuai dan mana yang tidak, dengan begitu peneliti tidak dipusingkan dengan datum-datum (meskipun mungkin menarik bagi peneliti) yang terlalu banyak yang pada gilirannya akan mempersulit peneliti sendiri dalam menganalisis data. Lebih lanjut, dalam penelitian kualitatif, fokus penelitian bersifat tentatif atau sementara, artinya bisa jadi fokus penelitian berubah ketika peneliti menemukan hal yang menarik di lapangan (Moleong, 1989).

Penelitian ini menggunakan metode studi kasus yang berusaha menggambarkan, menjelaskan dan menganalisis fenomena, peristiwa, aktivitas, kepercayaan, persepsi dan pemikiran secara individual dan kelompok. Dengan metode studi kasus, maka fakta mengenai masalah dan fokus penelitian dari berbagai sumber data akan digali, dianalisis dan diinterpretasikan untuk mengangkat substansi mendasar yang terdapat dibalik kasus yang diteliti. Studi kasus adalah suatu pendekatan yang digunakan untuk mempelajari, menerangkan, atau menginterpretasikan suatu kasus dalam konteksnya secara natural tanpa ada intervensi dari pihak luar. Sehingga yang membedakan metode studi kasus dengan metode penelitian kualitatif lainnya adalah mengenai kedalaman analisis pada kasus yang spesifik.

Penelitian ini berlokasi di Desa Bejiharjo Kec. Karangmojo, Kab. Gunung Kidul, Yogyakarta. Lokasi penelitian ini dipilih sebab terdapat fenomena menarik pada salah satu objek wisata di Bejiharjo yaitu Objek Wisata Goa Pindul yang menimbulkan polemik perebutan sumber daya yang ada. Data penelitian ini terdiri dari data primer dan data sekunder. Berikut adalah sumber data dalam penelitian ini yang terdiri dari dua jenis, yaitu:

\section{a) Informen Penelitian}

Informen penelitian termasuk kedalam data primer. Data primer adalah data yang diperoleh langsung dari informan penelitian dengan proses wawancara yang dijadikan objek penelitian. Data tersebut diperoleh dari hasil 
wawancara mendalam dengan informen tersebut. Informan penelitian merupakan orang yang menjadi sumber data dalam penelitian yaitu pokdarwis di Goa Pindul Kabupaten Gunung Kidul.

Teknik pemilihan informan dalam penelitian ini yaitu menggunakan teknik purposive. Teknik purposive merupakan teknik mengambilan sumber data dengan pertimbangan tertentu, orang yang dianggap paling tahu tentang permasalahan yang diteliti atau orang yang berkedudukan sebagai penguasa sehingga memudahkan peneliti untuk memahami obyek serta situasi sosial yang diteliti.

b) Dokumen Penelitian

Dokumen penelitian termasuk kedalam jenis data sekunder. Data sekunder yaitu data yang diperoleh dari lembaga atau instansi yang berwenang, berita dari surat kabar, dan dokumen-dokumen terkait lainnya.

Teknik pengumpulan data pada penelitian ini dilakukan melalui teknik observasi, wawancara mendalam, dokumentasi. Kemudian hal terakhir yang dilakukan adalah analisis data terhadap temuan substantif maupun temuan formal. Analisis data menjadi sebuah kegiatan yang dilakukan untuk mengatur, mengurutkan, mengelompokkan, memberi kode/tanda, dan mengkategorikan data sehingga diperoleh temuan yang sesuai dengan masalah yang ingin dijawab. Analisis data dalam penelitian kualitatif adalah proses mencari dan menyusun secara sistematis data yang diperoleh dari hasil wawancara, catatan lapangan dan dokumentasi, dengan cara mengorganisasikan data ke dalam kategori, menjabarkannya ke dalam unit-unit, melakukan sintesa, menyusun ke dalam pola, memilih mana yang penting untuk dipelajari dan membuat kesimpulan. Dengan begitu, data akan mudah dipahami oleh peneliti sendiri maupun orang lain (Sugiyono, 2006).

\section{Pembahasan}

\section{Representasi Politik di Obyek Wisata Goa Pindul}

Di Kabupaten Gunung Kidul terdapat berbagai destinasi obyek wisata, seperti Goa Emas, Goa Sriti, Telaga Banyu Bening, Situs Megalitikum, Goa Pindul dan lain-lain. Salah satu obyek wisata yang cukup mendapat perhatian dari pengunjung ialah wisata Goa Pindul yang terletak di Desa Bejiharjo Kec. Karangmojo, Kab. Gunung Kidul, Yogyakarta. Awalnya, Goa Pindul hanya sebuah aliran sungai yang digunakan untuk memandikan hewan. Namun, 
8 Harirah|, Muliawan, Fatkhurrohman Representasi Politik dalam...

setelah diadakan acara famtur oleh pejabat Kab. Gunung Kidul di desa bejiharjo pada bulan Oktober 2010 Goa Pindul berubah menjadi salah satu objek wisata yang menjanjikan.

Goa pindul awalnya dikelola oleh Dewa Bejo (Desa Wisata Bejiharjo) yang terdiri dari Pak Subagyo, Pak Suratmin, Pak Pramuji dan Mbah Tukijo. Setelah berjalan sekian lama, obyek wisata Goa Pindul semakin berkembang dan banyak pengunjungnya. Dewa bejo memiliki lebih dari 60 relawan pemandu wisata, sedangkan struktur organisasi Dewa Bejo dapat terlihat pada tabel di bawah ini:

Tabel 1.1

Struktur Organisasi Pokdarwis Dewa Bejo

\begin{tabular}{|c|c|}
\hline Jabatan & Nama \\
\hline Ketua & Subagyo \\
\hline Sekretaris & Pramuji \\
\hline Bendahara & Suratmin \\
\hline Bidang Pemandu & Tukijo \\
\hline Bidang Atraksi & Pariyo \\
\hline Bidang Home stay & Dian P \\
\hline Bidang keamanan & Sukarmanto \\
\hline Bidang Humas & Rismanto \\
\hline Bidang Konsumsi & Srini dan Tumirah \\
\hline
\end{tabular}

Sumber: Pokdarwis Dewa Bejo

Dari satu operator yaitu Dewa Bejo kemudian mulai bermunculan Kelompok Sadar Wisata (Pokdarwis) yang lainnya. Hingga saat ini terdapat 9 Pokdarwis yang masih aktif. Berdasarkan hasil wawancara dengan Bapak Suratmin bahwa setelah Goa Pindul menjadi sebuah obyek wisata, banyak warga Gunung Kidul yang merantau di Jakarta pulang kampung untuk menjadi pemandu wisata. Penghasilan sebagai pemandu wisata dapat mencapai 1 juta rupiah perbulannya dan pada saat liburan pendapatan tersebut bisa lebih. Harga tiket yang dibayar oleh para pengunjung untuk masuk ke Goa Pindul sebesar Rp.35,000, dengan memperoleh fasilitas pemandu, ban, dan baju renang dan sepatu air.

Kesuksesan Goa Pindul menjadi salah satu obyek wisata ternama menimbulkan konflik masalah kepemilikan tanah. Ketegangan diawali oleh 
tuntutan yang disampaikan oleh pihak Ibu Damayanti kepada para pokdarwis yang mengelolah Goa Pindul. Ibu Damayanti adalah warga asli di desa Bejiharjo dan merupakan pemilik lahan diatas Goa Pindul secara sah. Ibu Damayanti adalah pemilik sertifikat atas tanah yang berada di atas Goa Pindul, sehingga atas dasar itu, dia membangun klaim kebenarannya sebagai pemilik yang saya sacara hukum yang melibatkan Atik Damayanti dengan pengelola Goa Pindul. Hal ini lah yang kemudian menyebabkan timbulnya konflik-konflik terkait masalah siapa yang berhak mengelola dan mengapa berhak mengelola.

\section{Menguji Teori Representasi Berdasarkan Data dan Fakta di Obyek Wisata Goa Pindul}

Berangkat dari teori representasi Pitkin, tulisan ini hendak mengungkap praktik teori representasi sesuai data dan fakta di Goa Pindul dengan mengidentifikasi 2 hal besar. Pertama, mengidentifikasi indikator utama dalam teori representasi yaitu aktor-aktor yang menjadi agen, konstituen, kepentingan yang diwakili, dan tindakan yang dilakukan untuk mewujudkan kepentingan tersebut. Kedua, bentuk-bentuk representasi yang terjadi di Obyek Wisata Goa Pindul dalam memperebutkan resource yang melimpah tersebut.

\section{a. Identifikasi berdasarkan indikator}

Data yang diperoleh dari hasil wawancara dan observasi di Obyek Wisata Goa Pindul dapat diidentifikasi dengan indikator-indikator dalam teori representasi dan juga berdasarkan pembagian bentuk representasi menurut Hanna F. Pitkin, sebagai berikut:

\section{Identifikasi agen/elite}

Agen atau representative adalah kelompok yang mewakili kepentingan represented. Agen yang terdapat di Obyek wisata Goa Pindul terdiri dari beberapa pihak. Pertama, Kelompok Sadar Wisata (Pokdarwis) yang mengelola Goa Pindul terdiri dari Dewa Bejo, Wirawisata, Pancawisata, Tunas Wisata, Karya Wisata, Mliwis Putih, Soko Limo, Panji Wisata, Gelaran Indah, Sumber Banyu Moto, dan Taruna Wisata. Awalnya Goa Pindul hanya dikelola oleh Dewa Bejo yang kemudian muncul Pokdarwis Wirawisata, Pancawisata, Tunas Wisata, yang masuk dalam Dewa Bejo Grup untuk mengelola Goa Pindul. Sedangkan 
10 Harirah|, Muliawan, Fatkhurrohman Representasi Politik dalam...

pokdarwis-pokdarwis lain dibentuk karena juga merasa berhak mengelola obyek wisata Goa Pindul dan wisata lain yang ada di daerah pendirian pokdarwis tersebut.

Kedua, Atik Damayanti sebagai agen yang memiliki tanah diatas Goa seluas 2 Hektare dari luas 5 hektare. Ketiga yaitu mbah Iman sebagai sesepuh atau tokoh adat di Desa Bejiharjo. Keempat yaitu Kepala Desa Bejiharjo, Kepala Dusun Desa Bejoharjo. Agen selanjutnya yaitu kelompok masyarakat yang mengelola parkir dan Ketua Joki.

\section{Identifikasi Konstituen}

1. Pokdarwis Goa Pindul

Dibawah ini merupakan konstituen dari masing-masing pokdarwis yang ada di Objek Wisata Goa Pindul Kabupaten Gunung Kidul:

a) Dewa Bejo mewakili masyarakat Dusun Gelaran 1. Tokoh yang berpengaruh adalah Pak subagyo, pak Suratmin, Pak Pramuji, dan Mbak Tukijo. Dewa Bejo merupakan perintis pengelolaan Goa Pindul. Dewa bejo merasa pihak yang paling berhak mengelola Goa Pindul. Sehingga pokdarwis-pokdarwis lain yang memasukkan Goa Pindul sebagai destinasi wisatanya harus melakukan koordinasi dengan Dewa Bejo Group dengan sistem bagi hasil.

b) Wirawisata didirikan pada akhir 2011 mewakili karang taruna Dusun Gelaran 2. Ketua Wirawisata meminta aset di daerah Goa Pindul juga karena merasa Goa Pindul adalah aset alam sehingga siapapun berhak mengelolanya. Sehingga Dewa Bejo tidak bisa melarang karena belum ada peraturan yang mengatur.

c) Pancawisata mewakili masyarakat Dusun Gelaran Gunung Bang

d) Tunas Wisata mewakili Dusun gunung Bang tetapi lokasinya agak jauh Goa Pindul. Sedangkan Pancawisata yang juga ada di dusun Gelaran Gunung Bang berada sekitar 200 m dari Goa Pindul

e) Karya Wisata mewakili masyarakat Dusun Karangmojo yang didalamnya terdapat obyek wisata Goa Sriti namun juga memasukkan Goa Pindul sebagai destinasi wisatanya sehingga Pokdarwis Karya Wisata harus menjalin kerjasama dengan Pokdarwis sebelumnya yaitu melalui Dewa Bejo dan Tunas wisata.. Karena berdasarkan Peraturannya, satu destinasi wisata hanya boleh dikelola oleh satu pokdarwis. Namun pada pelaksanaanya seringkali Karya Wisata tidak 
melakukan koordinasi dengan Dewa Bejo dan Tunas Wisata

f) Mliwis Putih mewakili daerah Dusun Banyubening 1 dengan obyek wisatanya telaga. Pokdarwis ini juga ikut mempromosikan Goa Pindul sebagai obyek wisatanya namun juga harus melalui pokdarwis pengelola Goa Pindul.

g) Soko Limo mewakili Dusun Sokoliman yang didirikan karena memiliki situs megalitikum sebagai obyek wisatanya namun juga tetap ikut mempromosikan Goa Pindul melalui pokdarwis pengelola Goa Pindul.

h) Panji Wisata mewakili Dusun Seropan, dengan potensi wisatanya yaitu Goa Emas dan Goa Greng

i) Sumber Banyu Moto mewakili Gelaran 1

j) Taruna Wisata dipimpin oleh Ziput dan Edi Purwanto yang merupakan warga luar wilayah Desa Bejiharjo. Sehingga keberadaan pokdarwis ini ditolak oleh masyarakat Bejiharjo

k) Gelaran Indah dipimpin oleh Pak Sugito yang merupakan saudara mbah Tukijo. Proses pembentukan pokdarwis ini tidak mengatasnamakan masyarakat manapun melainkan atas keinginan pribadi. Memasukkan Goa Pindul tanpa mengkonfirmasi dengan Pokdarwis Goa Pindul (Dewa Bejo Grup yaitu Dewa Bejo, Tunas Wisata, Wirawisata, dan Panca Wisata). Proses pembentukan pokdarwis ini langsung ke Pemerintah daerah karena memiliki link di Pemerintah Daerah tersebut.

2. Atik Damayanti merupakan elite yang tidak mewakili kepentingan siapa-siapa karena Atik memperjuangkan kepentingan pribadinya yang menginginkan keuntungan dari Goa Pindul atas tanah yang dimilikinya di wilayah atas Goa Pindul

3. Mbah Iman merupakan tokoh adat yang menolak pemanfaatan Goa Pindul sebagai obyek wisata karena alasan mistis. Dan hal itu didukung oleh kelompok masyarakat adat yang juga percaya dengan hal itu.

4.Kepala Desa Bejiharjo yaitu Bapak Yanto yang memiliki kaitan dengan pengelolaan Goa Pindul karena mengeluarkan SK Desa Wisata Bejiharjo terkait Obyek Wisata Goa Pindul. Kepala desa Bejiharjo ini mengakomodir kepentingan-kepentingan yang ada di Goa Pindul untuk menyelesaikan permasalahan yang ada dan berusaha bersikap netral. Masyarakat merasa berhasil dengan kepemimpinan Pak Yanto ini karena 
proses komunikasi nya dilakukan dengan baik.

5.Kepala Dukuh merupakan tokoh yang juga berkaitan dengan pengelolaan Goa Pindul sebagai penasehat Pokdarwis, Kepala dukuh hadir dalam rapat-rapat.

6.Pengelola Parkir di Goa Pindul berbeda dengan pengelolaan wisata Goa Pindul. Parkir yang ada dikelola oleh warga yang mengatasnamakan Karang Taruna.

7. Ketua Joki yaitu Bapak Leo mewakili joki-joki yang ada di wilayah Goa Pindul yang seringkali menimbulkan kesalahfahaman antar Pokdarwis.

\section{Identifikasi Kepentingan yang Diwakilkan}

Dari 11 pokdarwis yang ada, 9 pokdarwis mewakili kepentingan warga dimana pokdarwis tersebut didirikan untuk bersama-sama meningkatkan kesejahteraan masyarakat dusun tersebut. Karena berdasarkan hasil wawancara, pokdarwis tersebut mempekerjakan masyarakat di wilayahnya sehingga masyarakat tersebut tidak lagi menjadi pengangguran dan keadaan perekonomiannya meningkat. Sehingga antar pokdarwis terkadang terjadi perebutan pelanggan.

Selain itu pokdarwis yang tidak masuk kedalam Dewa Bejo Group seringkali tidak melakukan koordinasi jika ada pelanggan yang ingin masuk ke Goa Pindul untuk menghindari sistem bagi hasil. Sedangkan 2 Pokdarwis lain yaitu Gelaran Indah dan Taruna Wisata tidak mewakili kepentingan massyarakat manapun melainkan memperjuangkan kepentingan pribadinya untuk memperoleh keuntungan dari Obyek Wisata Goa Pindul.

Agen lain yaitu Ibu Atik Damayanti tidak memperjuangkan kepentingan kelompok lain melainkan memperjuangkan kepentingan pribadinya. Pada tahun 1988 tanah di atas Goa Pindul di beli oleh Bapak Ziput, namun karena Pak Ziput bukan masyarakat asli Bejiharjo sehingga tanah tersebut diatasnamakan Atik Damayanti yang merupakan adik iparnya. Sehingga ketika Goa Pindul semakin berkembang dan mendatangkan banyak wisatawan, maka Bu Atik Damayanti juga menginginkan untuk ikut menikmati hasilnya karena merasa wilayah itu juga merupakan tanah miliknya dengan meminta Rp.20.000 dari setiap tiket yang terjual. Karena hal itu tidak berhasil sehingga bu Atik memperjuangkan mulai dengan cara meminta agar Goa Pindul ditutup sampai dengan melaporkan ke aparat kepolisian. 
Agen berikutnya yaitu mbah Iman memperjuangkan masyarakat yang masih percaya dengan nilai-nilai budaya jawa yang ada karena menganggap pembukaan Goa Pindul sebagai lokasi wisata dapat memakan korban dengan alasan mistis. Karena dulunya, Goa Pindul merupakan tempat persemedian. Kepentingan yang diwakili oleh Kepala Desa dan Kepala dukuh hanya seputar untuk menjaga ketertiban dari pengelolaan Goa Pindul.

Agen lain yaitu pengelola parkir yang mengatasnamakan Karang Taruna sebenarnya tidak benar-benar mengatasnamakan karang taruna. Karena pada prakteknya, wilayah parkir ini menjadi arena memperoleh hasil yang dinikmati oleh segelintir orang yang mengatasnamakan karang taruna. Agen yang terakhir yaitu Ketua Joki mewakili kepentingan joki-joki lainnya yang berusaha mencari pelanggan dengan menurunkan harga tiket masuk ke Goa Pindul.

\section{Identifikasi Respon Agen}

Cara agen merespon konstituen dilakukan dengan 3 cara, yaitu dengan mengikuti keinginan konstituen, mengikuti penilaiannya sendiri, dan menyesuaikan dengan kondisi politik. Dari hasil pemaparan diatas, maka agen yang merespon konstituennya dengan mengikuti keinginan konstituennya ialah pertama, 9 pokdarwis aktif yang merespon kepentingan-kepentingan masyarakatnya yang diwakilinya dilakukan dengan musyawarah mencari solusi terbaik dan tidak ada pihak yang dominan. Kedua, Kepala Desa dan Kepala Dukuh merespon kepentingan masyarakat yang tergabung dalam pokdarwis dengan membantu menyelesaikan konflik yang terjadi dan berusaha melakukan komunikasi sebaik mungkin terhadap pokdarwis yang ada sehingga tidak memihak.

Selanjutnya, respon agen dengan mengikuti penilaiannya sendiri terdiri dari Bu Atik Damayanti, Pokdarwis Gelaran Indah dan Taruna Wisata, Juru Parkir yang tidak mengakomodir kepentingan karang taruna yang diwakilinya, dan Ketua Joki yang bertindak secara dominan terhadap kepentingan joki-joki yang diwakilinya. Karena Ketua Joki ini dianggap memiliki kemampuan lebih dan juga awalnya merupakan seorang marketing dari Pokdarwis Tunas wisata namun pada akhirnya memisahkan diri dan menjadi joki.

Terakhir, Respon agen dengan menyesuaikan diri terhadap kondisi politik adalah mbah Iman, karena awalnya mbah Iman menolak atau melarang pembukaan Goa Pindul sebagai tempat wisata, namun kemudian mbah Iman 
14 Harirah|, Muliawan, Fatkhurrohman Representasi Politik dalam...

akhirnya setuju karena keinginan untuk menjadikan Goa Pindul sebagai tempat wisata adalah keinginan pemerintah dan masyarakat.

\section{b. Identifikasi Berdasarkan Bentuk-Bentuk Representasi}

Selain berdasarkan indikatornya, dalam tulisan ini juga akan dilakukan pengidentifikasian agen/elite berdasarkan pendapat Hanna F. Pitkin yang membagi representasi kedalam empat bentuk, yaitu representasi substantif, representasi simbolik, representasi deskriptive, dan representasi formal. Berdasarkan identifikasi indikator teori representasi diatas, maka agen-agen dalam konflik Goa Pindul tersebut dapat dipetakan menurut bentuk-bentuk representasinya menurut Hannah Pitkin tersebut, yaitu:

\section{a) Representasi Formal}

Representasi formal sebagai sebuah bentuk representasi yang dilihat dari statusnya yang didalamnya terdapat otoritas dan akuntabilitas. Sehingga agen yang termasuk kedalam bentuk representasi formal adalah

$\checkmark \quad$ Badingah (Bupati Gunung Kidul)

$\checkmark$ Suryoaji (Kepala Dinas Pariwisata)

$\checkmark$ Yanto (Kepala Desa)

$\checkmark \quad$ Edi Purwanto (Anggota DPRD Gunung Kidul)

$\checkmark \quad$ Ali Martono (Pegawai Dinas)

Seluruh agen dari representasi formal tersebut mewakili kepentingan dari Pemerintah dalam hal melaksanakan tugas dan fungsinya. Representasi formal dipahami sebagai perwakilan politik yang berlangsung di dalam lembaga-lembaga perwakilan formal

b) Representasi Simbolik

Representasi simbolik yaitu keterwakilan karena kesamaan kultur, kepercayaan, dan identifikasi. Agen yang termasuk kedalam representasi simbolik pada fenomena konflik Goa Pindul adalah mbah Iman. Hal tersebut dikarenakan mbah Iman sebagai seseorang tokoh masyarakat yang masih memegang teguh budaya jawa yang masih kental dengan hal-hal mistis.

c) Representasi Substantif

Representasi Substantif merupakan representasi dari agen yang benarbenar memperjuangkan kepentingan yang diwakilinya (konstituen). Dalam fenomena konflik Goa Pindul di Kabupaten Gunung Kidul tersebut, yang menjadi representasi substantif adalah 
$\checkmark$ Subagyo (Ketua Pokdarwis Dewa Bejo)

$\checkmark$ Budi Hardiyanto (Ketua Pokdarwis Wirawisata)

$\checkmark$ Sukiyat (Ketua Pokdarwis Tunaswisata)

Ketiga ketua pokdarwis tersebut masuk kedalam jenis representasi substantif dikarenakan mempunyai legitimasi dari Pemerintah. Pemerintah menjadikan ketua ketiga pokdarwis ini sebagai pijakan saat Pemerintah membutuhkan informasi mengenai Goa Pindul. Pada awalnya, masyarakat Bejiharjo diwakili secara substantif oleh Pokdarwis Dewa Bejo, Pokdarwis Wirawisata dan Pokdarwis Tunaswisata. Representasi substantif yang dimainkan oleh Pak Subagyo, Pak Budi Hardiyanto, dan Pak Sukiyat berkaitan dengan upayanya memperjuangkan kelompok masyarakat sadar wisata yang ingin mengelola Goa Pindul. Mereka mengatasnamakan kepentingan masyarakat Bejiharjo secara keseluruhan yang menganggap bahwa Goa Pindul merupakan aset publik yang berhak dikelola oleh masyarakat luas.

Namun dalam perjalanannya, terjadi pergeseran fungsi representasi oleh ketiga Pokdarwis tersebut yang tidak lagi memperjuangkan kepentingan masyarakat Bejiharjo menjadi hanya mewakili kelompok masing-masing Pokdarwis saja. Ketiga pokdarwis ini termasuk kedalam jenis representasi substantif meskipun pada akhirnya representasi substantif tersebut dipertanyakan.

d) Representasi Deskriptif

Representasi deskriptif yaitu representasi karena adanya tingkat kemiripan antara yang mewakili dengan yang diwakili misalnya kesamaan wilayah, komunitas, kelompok, gender, dll, Agen yang termasuk dalam kelompok ini adalah

$\checkmark$ Ketua-ketua Pokdarwis di Desa Bejiharjo yaitu

$>$ Tri Gunadi (Ketua Pokdarwis Pancawisata)

$>$ Ristanto (Ketua Karya Wisata)

> Sarianto (Ketua Pokdarwis Mliwis Putih)

> Gimu (Ketua Pokdarwis Soko Limo)

> Sugito (Ketua Pokdarwis Gelaran Indah)

$>$ Agung (Ketua Pokdarwis Sumber)

$\checkmark$ Leo (Ketua Joki) 
16 Harirah|, Muliawan, Fatkhurrohman Representasi Politik dalam...

Keseluruhan agen tersebut dikategorikan menjadi representasi deskriptif dikarenakan mewakili kelompok-kelompok atas dasar kesamaan wilayah dan kepentingan.

\section{Limitasi Teori Representasi berdasarkan Konflik di Goa Pindul berdasarkan Temuan di Lapangan}

Dari penjelasan diatas, penulis menemui kejanggalan terkait fakta yang terjadi dilapangan yang tidak sesuai dengan teori representasi.

1. Tidak setiap agen memiliki konstituen yang jelas (konstituen semu)

Fenomena agen yang tidak memiliki konstituen secara real terlihat pada Ny. Atik Damayanti yang melakukan berbagai upaya tidak untuk membela kepentingan konstituennya. Sebagai seorang agen keterlibatan Atik Damayanti dalam pusaran konflik di Gua Pindul karena memiliki klaim atas tanah diatas Gua Pindul berdasarkan legalitas kepemilikan melalui sertifikat. Perjuangan Atik Damayanti dilakukan untuk memperjuangkan atau membela kepentingan keluarga dan pendukungnya atas status kepemilikan sertifikat tanah di atas Goa Pindul. Atik Damayanti berusaha menguasai Goa Pindul dengan berbagai cara, mulai dari bekerja sama dengan Siput dan anggota DPRD yaitu Edi Purwanto.Dengan bantuan dari Edi Purwanto, mereka menggerakkan preman untuk menutup Goa Pindul sebagai tempat wisata, melakukan pemberitaan di media massa untuk menjatuhkan Dewa Bejo, dan mengadukan halnya kepada aparat penegak hukum mulai dari level lokal hingga nasional.

Dalam perjangan melawan Pokdarwis Dewa Bejo untuk berebut hak pengelolaan Gua Pindul, Atik Damayanti mengandalkan keluarga dan pendukungnya untuk mengadvokasi kepentingannya. Artinya tindakantindakan tersebut murni dilakukan untuk mengejar kepentingan ekonomi dari keluarga dan pendukungnya bukan untuk kepentingan masyarakat di kawasan Gua Pindul secara umum.

2. Terdapat elit atau agen yang memerankan lebih dari satu bentuk representasi (multi tasking)

Fakta dimana terdapatnya agen yang memerankan lebih dari satu jenis representasi (multi tasking) adalah sebuah fenomena unik dalam mengurai representasi elit pada konflik di Gua Pindul. Suyanto sebagai kepala Desa Bejiharjo secara ideal seharusnya berperan sebagai elit yang bertindak atas nama pemerintah akan tetapi tidak jarang Suyanto sebagai kepala Desa juga 
memainkan peran ganda, dimana dia juga dalam merespon suatu isu berkaitan dengan Gua Pindul justru terlihat mewakili kelompok Pokdarwis dan disaat yang lain membela pemerintah. Suyanto dalam beberapa kesempatan memberikan respon atau opini melalui media mengenai wisata Gua Pindul dalam rangka mewakili kepentingan pemerintah, misalkan dia mengatakan mengenai upaya pemerintah untuk menjadikan Desa Bejiharjo sebagai Desa Wisata

Selain itu Suyanto sebagai kepala Desa juga memberikan pernyataan yang mendukung Pemerintah dengan memberikan dukungan dan partisipasi masyarakat Desa Bejiharjo. Sehingga dalam enam tahun kedepan, desa ini menjadi barometer wisatawan baik ditingkat lokal maupun internasional.

Akan tetapi dalam beberapa kesempatan yang lain Suyanto juga dalam memberikan opini yang justru seakan dalam rangka mewakili kelompok Pokdarwis khususnya Dewa Bejo. Melalui media masa pak Suyanto justru memberikan opini yang membela atau menguntungkan kepentingan Pokdarwis Dewa Bejo bahwa dalam operasinya, Dewa Bejo juga mengantongi HO berupa persewaan ban, pelampung dan usaha transportasi" (Widiyanto, 2013).

Dalam petikan opini di media sangat jelas bagaimana pak Suyanto berbicara untuk mempromosikan Dewa Bejo sebagai pengelola wisata yang layak karena telah mengantongi HO berupa persewaan ban, pelampung dan usaha transportasi. Selain itu pada media massa lain beliau memberikan opini bahwa telah menerima Raperda kepariwisataan dari Pemkab, sehingga bersedia merealisasikan tiket satu pintu (Harjo, 2013). Opini ini menjadi aneh sebab yang seharusnya menyatakan siap untuk merealisasikan aturan tiket satu pintu adalah pihak Pokdarwis sebagai pengelola wisata Gua Pindul. Sehingga dengan adanya opini yang demikian menunjukan bahwa pak Suyanto sedang berbicara mewakili kelompok Pokdarwis.

\section{Kritik Teori Representasi Hannah Pitkin}

Berdasarkan temuan-temuan tersebut, maka penulis berkesimpulan bahwa teori representasi menurut Hanna Pitkin tidak mampu menjelaskan fenomena representasi yang terjadi di Obyek Wisata Goa Pindul.

1. Empat model representasi yang ditawarkan Hannah Pitkin kurang memadai untuk menjelaskan fenomena representasi di Goa Pindul. Konsep 
18 Harirah|, Muliawan, Fatkhurrohman Representasi Politik dalam...

representasi yang ditawarkan oleh Hannah Pitkin menyatakan bahwa setiap agen yang ada bertindak atas nama dan dalam rangka memperjuangkan kepentingan konstituennya. Oleh karena itu konsep diatas menyimpulkan bahwa setiap elit atau agen memiliki konstituen yang kepentingannya akan diperjuangkan. Fenomena yang terjadi di Goa Pindul yaitu keterlibatan Atik Damayanti justru memperlihatkan hal yang berbeda dari konsep yang ditawarkan oleh Hannah Pitkin. Fenomena hadirnya agen yang tidak memiliki konstituen secara nyata dalam pertarungan kepentingan di Goa Pindul merupakan sebuah fenomena yang tidak mampu terjelaskan oleh teori representasi yang disebutkan oleh Hannah Pitkin. Fenomena yang tidak mampu dijelaskan oleh konsep representasi Hannah Pitkin tersebut menunjukan bahwa tindakan agen tidak selamanya ditentukan atau ditujukan untuk membela kepentingan konstituen tetapi tindakan agen justru ditentukan atau ditujukan untuk memperjuangkan kepentingan elit itu sendiri dan keluarganya. Sehingga keterbatasan teori Representasi oleh Hannah Pitkin tidak mampu mengidentifikasi bahwa terdapat konstituen semu. Fenomena representasi yang sifatnya elitis tersebut yang menurut Olle Tornquist disebut sebagai representasi mengambang (Tornquist \& dkk, 2009).

2. Konsep representasi yang ditawarkan oleh Hanna Pitkin mengalami keterbatasan untuk menjelaskan fenomena representasi di Gua Pindul. Dalam empat konsep yang disebutkan oleh Hannah Pitkin mengenai representasi memandang bahwa setiap elit atau agen hanya bersikap monolitik. Artinya bahwa satu elite hanya akan termasuk kedalam satu jenis representasi saja sehingga elit akan hanya memerankan atau bertindak berdasarkan satu jenis representasi. Fenomena yang terjadi dalam konflik di Gua Pindul menunjukan sesuatu yang berbeda dari gagasan yang disampaikan oleh Hannah Pitkin tersebut. Fenomena yang terjadi dalam konflik di Gua Pindul menunjukan bahwa agen dalam memperjuangkan kepentingan konstituennya tidak selamanya berdiri diatas satu jenis representasi saja, melainkan dapat memainkan atau memerankan berbagai jenis representasi (multi tasking). 


\section{Kesimpulan}

Fenomena konflik obyek wisata Goa Pindul menimbulkan bertebarannya perwakilan-perwakilan atau agen-agen yang berdiri untuk membela kepentingan konstituen. Dari identifikasi terhadap fenomena representasi yang terjadi di Goa Pindul terdapat beberapa hal yang tidak dapat dijelaskan atau oleh teori representasi menurut Hanna Pitkin. Pertama, terdapatnya agen yang tidak memiliki konstituen secara nyata atau ril (konstituen semu) yakni masyarakat sehingga dalam perjuangan dalam konflik yang terjadi di Gua Pindul agen mengatasnamakan dan membela kepentingan keluarga dan kelompoknya. Kedua, dalam fenemena representasi yang terjadi pada pusaran konflik Gua Pindul ditemukan adanya elit yang memainkan peran lebih dari satu jenis representasi (multi tasking). Hal ini menjadi penting, sebab dalam konsep representasi yang ditawarkan oleh Hannah Pitkin bahwa dalam representasi elit atau agen bersifat monolitik artinya bahwa agen hanya akan bertindak atau memerankan satu jenis representasi.

\section{Saran}

Kajian mengenai representasi politik menjadi kajian yang menarik untuk diteliti secara mendalam dari berbagai sudut pandang. Kajian demi kajian diharapkan mampu menambah khasanah ilmu politik di bidang relasi agen dan konstituen dalam mengelola suatu sumber daya alam. Sehingga dari kajian yang sederhana ini diharapkan mampu menumbuhkembangkan kepekaan peneliti lainnya untuk mengkaji fenomena representasi politik yang selalu hadir dalam konteks sosial yang berbeda.

\section{DAFTAR PUSTAKA}

Bayu. (2015, September 4). Gunung Kidul Post. Dipetik Desember 14, 2015, dari Gunung Kidul Post: http://www.gunungkidulpost.com/2015/10/dari-tukang-tas-jadikades.html

Darmawan, I. (2017). Menggugat (Praktik) Representasi Politik. Jurnal Politik Vol 2 No 2, 365-370. 
20 Harirah|, Muliawan, Fatkhurrohman Representasi Politik dalam...

Ekawati, E. (2014). Dari Representasi Politik Formal ke Representasi Politik Non-Elektoral. Jurnal Penelitian Politik Vol II No 2, 129-136.

Ezrow, L. (2010). Rethinking Citizens and Parties: How Electoral System Matter for Political Representation. Oxford: Oxford University Press.

Fatoni, M. (2011, Februari 22). Tribun Jogja. Dipetik Desember 14, 2015, dari Tribun Jogja: http://www.jogja.tribunnews.com/2011/02/22/suparnosenang-bejiharjo-jadi-desa-wisata.html

Harjo. (2013, Desember 12). Gunung Kidul Online. Dipetik Desember 14, 2015, dari Gunung Kidul Online: http://www.gunungkidulonline.com/wisatagunungkidul-muncul-wacana-tiket-masuk-satu-pintu.html

Hendarti, B. (2013). Perempuan Menuju Kursi Parlemen Tahun 2013: Membangun Asetivitas Perempuan pada Kekuasaan Politik. Jurnal Perempuan Vol 18 No 4.

Jati, W. R. (2014). Historitas Politik Perempuan Indonesia. Jurnal Paramita Vol 24 No 2, 200-210.

Moleong, L. J. (1989). Metodologi Penelitian Kualitatif. Bandung: CV Remadja Karya.

Pitkin, H. F. (1967). The Concept of Representation. Barkeley: University of California.

Rajab, B. (2018). Representasi Perempuan dalam Lembaga Politik di Indonesia. Jurnal Masyarakat dan Budaya Vol 20 No 2, 553.

Rozaki, A., \& dkk. (2014). Dari Representasi Simbolik Menuju Representasi Substatif. Yogyakarta: IRE.

Soraya, D. F. (2012). Representasi Perempuan di Parlemen. Jakarta: Skripsi Fisipol UI.

Subiantoro, B. E. (2013). Masa Depan Keterwakilan Perempuan dalam Pemilu Legislatif 2014. Jurnal Perempuan Vol 18 No 4.

Sugiyono. (2006). Metode Penelitian Kuantitatif dan R\&D. Bandung: Alfabeta.

Suratmin. (2015, Oktober 26). Salah satu pengelola Pokdarwis Dewa Bejo. (Z. H. MS, Pewawancara)

Tornquist, O., \& dkk. (2009). Rethinking Popular Representation. Palgave: Macmillan.

Tremblay, M. (. (2008). Woman and Legislative Representation: Electoral Systems, Political Parties, and Sex Quotas. New York: Palgrave Macmillan. 
Harirah|, Muliawan, Fatkhurrohman Representasi Politik dalam...| 21

Widiyanto, D. (2013, Juli 5). KRJogja. Dipetik Desember 14, 2015, dari KRJogja: http://www.krjogja.com/read/163135/berebut-rupiah-goapindul.html

Wijaksana, M. (2004). Modul Perempuan untuk Politik: Sebuah Panduan tentang Partisipasi Perempuan dalam Politik. Jakarta: Yayasan Jurnal Perempuan. 